\title{
Somatostatin-Induced Regulation of $\mathrm{SST}_{2 \mathrm{~A}}$ Receptor Expression and Cell Surface Availability in Central Neurons: Role of Receptor Internalization
}

\author{
Hélène Boudin,, ${ }^{1}$ Philippe Sarret, ${ }^{2}$ Jean Mazella, ${ }^{2}$ Agnes Schonbrunn, ${ }^{3}$ and Alain Beaudet ${ }^{1}$ \\ ${ }^{1}$ Montreal Neurological Institute, McGill University, Montréal, Québec H3A 2B4, Canada, 2Institut de Pharmacologie \\ Moléculaire et Cellulaire, Centre National de la Recherche Scientifique, Université de Nice-Sophia Antipolis, Valbonne, \\ France, and 3University of Texas, Houston Medical School, Houston, Texas 77225
}

\begin{abstract}
To investigate the effects of somatostatin (somatotropin releaseinhibiting factor, SRIF) on the regulation of $\mathrm{SST}_{2 \mathrm{~A}}$ receptors in mammalian brain, we examined how blockade of SRIF release or stimulation by the SRIF analog [D-Trp ${ }^{8}$ ]-SRIF would affect the expression and cell surface availability of $\mathrm{SST}_{2 \mathrm{~A}}$ receptors in rat brain slices. First, we measured the intensity of $\mathrm{SST}_{2 \mathrm{~A}}$ immunoreactivity, using quantitative light microscopic immunocytochemistry, and levels of $\mathrm{SST}_{2 \mathrm{~A}} \mathrm{mRNA}$, using semiquantitative RT-PCR, under conditions of acute SRIF release blockade. Incubation of slices from the claustrum or basolateral amygdala, two regions previously shown to contain high concentrations of $\mathrm{SST}_{2 \mathrm{~A}}$ receptors, in $\mathrm{Ca}^{2+}$-free Ringer's for 40 min induced a decrease in the intensity of $\mathrm{SST}_{2 \mathrm{~A}}$ receptor immunoreactivity and concentration of $\mathrm{SST}_{2 \mathrm{~A}} \mathrm{mRNA}$ as compared with control values obtained in $\mathrm{Ca}^{2+}$-supplemented Ringer's. These effects were counteracted in a dose-dependent manner by the addition of
\end{abstract}

Somatostatin (somatotropin release-inhibiting factor, SRIF) is a biogenic peptide widely distributed in brain and periphery (for review, see Patel, 1992). Originally identified on the basis of its ability to inhibit growth hormone secretion from the pituitary (Brazeau et al., 1973), it since has been found to exert a variety of hormonal and neural actions (Epelbaum, 1986). SRIF exists under two forms, derived from the same precursor molecule: a 14-aminoacid short form (SRIF-14) and an N-terminally extended form of the latter, SRIF-28 (for review, see Patel, 1992). Both forms coexist in the brain; however, SRIF-14 is the one that appears to play a predominant role (Johansson et al., 1984; Patel, 1992). Both central and peripheral actions of SRIF are mediated by G-protein-coupled receptors, five of which, designated $\mathrm{SST}_{1-5}$ (Hoyer et al., 1995), have been cloned so far (Bruno et al., 1992; Kluxen et al., 1992; Meyerhof et al., 1992; O'Carroll et al., 1992; Yamada et al., 1992; Yasuda et al., 1992). All of these receptors bind SRIF-14 and SRIF-28 with comparable affinities except for $\mathrm{SST}_{5}$, which exhibits a slightly higher affinity for SRIF-28 than for SRIF-14 (O'Carroll et al., 1992; Hoyer et al., 1994; Reisine and Bell, 1995; Siehler et al., 1998).

The distribution of SRIF binding sites in rat brain was first established by using radioligand binding and receptor autoradiographic techniques (for review, see Krantic et al., 1992). Since then molecular biological studies have demonstrated that all five sub-

\footnotetext{
Received Feb. 28, 2000; revised May 10, 2000; accepted May 25, 2000.

This work was supported by Medical Research Council of Canada Grant MT-7366 to A.B. and National Institutes of Health Grant DK32234 to A.S. H.B. was funded by Institut National de la Santé et de la Recherche Médicale Fonds de la Recherche en Santé du Québec and Jeanne Timmins research fellowships. We thank Mariette Houle for excellent technical assistance and Naomi Takeda for her help with the preparation of this manuscript.

Correspondence should be addressed to Dr. Alain Beaudet, Montreal Neurological Institute, McGill University, 3801 University Street, Montréal, Québec H3A 2B4, Canada. E-mail: mcin@musica.mcgill.ca.

Copyright (C) 2000 Society for Neuroscience $0270-6474 / 00 / 205932-08 \$ 15.00 / 0$
}

10-100 nm [D-Trp $\left.{ }^{8}\right]-$ SRIF to the $\mathrm{Ca}^{2+}$-free medium. Furthermore, both of these effects were abolished in the presence of the endocytosis inhibitors phenylarsine oxide or hyperosmolar sucrose, suggesting that they were dependent on receptor internalization. Electron microscopic immunogold labeling confirmed the existence of an agonist-induced internalization of $\mathrm{SST}_{2 \mathrm{~A}}$ receptors in central neurons. At a high $(10 \mu \mathrm{M})$, but not at a low $(10 \mathrm{~nm})$, concentration of agonist this internalization resulted in a significant decrease in cell surface receptor density, irrespective of the presence of $\mathrm{Ca}^{2+}$ in the medium. Taken together, these results suggest that ligand-induced endocytosis is responsible for rapid transcriptional (increase in $\mathrm{SST}_{2 \mathrm{~A}}$ expression) and trafficking (loss of cell surface receptors) events involved in the control of the somatostatinergic signal.

Key words: somatostatin; endocytosis; receptor; immunocytochemistry; electron microscopy; signaling types of SRIF receptors are expressed in mammalian CNS (Bruno et al., 1993; Raulf et al., 1994; Viollet et al., 1995). Messenger RNAs for $\mathrm{SST}_{1-5}$ receptor subtypes were localized in adult rodent brain by in situ hybridization (Breder et al., 1992; Kaupmann et al., 1993; Kong et al., 1994; Pérez et al., 1994; Señarís et al., 1994; Beaudet et al., 1995; Thoss et al., 1995), and SST receptor proteins were visualized at cellular and subcellular levels by immunocytochemistry (Dournaud et al., 1996; Schindler et al., 1997, 1999; Helboe et al., 1998; Hervieu and Emson, 1998; Händel et al., 1999; Stroh et al., 1999). Most of these studies concur in reporting an extensive brain distribution for $\mathrm{SST}_{2}$ and particularly for its splice variant $\mathrm{SST}_{2 \mathrm{~A}}$, a somewhat more restricted distribution for $\mathrm{SST}_{1}$ and $\mathrm{SST}_{3-4}$, and a limited distribution for $\mathrm{SST}_{5}$.

Recent studies have shown that the interaction of SRIF with its receptors resulted in a temperature- and receptor-dependent internalization of receptor-ligand complexes in cell lines expressing either native (Koenig et al., 1997; Sarret et al., 1999) or recombinant (Hukovic et al., 1996; Hipkin et al., 1997; Nouel et al., 1997; Roth et al., 1997; Stroh et al., 2000b) SRIF receptor subtypes. However, studies on transfected cells have shown major differences between subtypes in both patterns and efficiency of internalization (Hukovic et al., 1996; Nouel et al., 1997; Roth et al., 1997). Briefly, high internalization yields were observed for $\mathrm{SST}_{2}, \mathrm{SST}_{3}$, and $\mathrm{SST}_{5}$ receptors, whereas poor internalization yields were found for $\mathrm{SST}_{1}$ and $\mathrm{SST}_{4}$ subtypes (Hukovic et al., 1996; Hipkin et al., 1997; Nouel et al., 1997; Roth et al., 1997; Kreienkamp et al., 1998; Stroh et al., $2000 \mathrm{~b})$. SRIF analogs also have been reported to internalize in neurons in primary culture via $\mathrm{SST}_{2}$ and other unidentified (but likely $\mathrm{SST}_{3}$ ) SST subtypes (Stroh et al., 2000a). There is also immunocytochemical evidence for SRIF-induced internalization of $\mathrm{SST}_{2 \mathrm{~A}}$ receptors in human glioma cells (Krisch et al., 1998) and intact rat brain (Dournaud et al., 1998). Little is known, however, about the implication of this internalization process for brain function. 
As for other G-protein-coupled receptors, ligand-induced SRIF receptor internalization has been proposed to be involved in receptor desensitization via cell surface receptor downregulation (Hipkin et al., 1997; Beaumont et al., 1998). Recent studies have also raised the possibility that internalization may play a role in transmembrane signaling. Evidence for internalization-induced signaling mainly stems from the study of growth factor and cytokine receptors (for review, see Bevan et al., 1995). However, changes in the duration of inositol phosphate accumulation and associated calcium responses (Griendling et al., 1987; Hunyady et al., 1991), as well as in transcription of receptor mRNA (Souazé et al., 1997), have been linked to impaired G-protein-coupled receptor internalization. Furthermore, ligand-induced receptor internalization recently was shown to be critical for the inhibition of growth hormone expression by SRIF in AtT-20 cells (Sarret et al., 1999).

The aim of the present study was to investigate the consequences of SRIF internalization in rat brain, specifically with regard to cell surface regulation of the $\mathrm{SST}_{2 \mathrm{~A}}$ receptor subtype and the potential role of the internalization process in SRIF-induced transcriptional effects. For this purpose we examined, using light and electron microscopic immunocytochemistry and semiquantitative PCR, the expression and distribution of $\mathrm{SST}_{2 \mathrm{~A}}$ receptors in rat brain slices exposed to various concentrations of SRIF.

\section{MATERIALS AND METHODS}

\section{Slice preparation}

Adult male Sprague Dawley rats (200-250 gm) were decapitated, and their brains were removed rapidly and blocked on a vibratome chuck. Coronal sections containing the claustrum and the basolateral nucleus of the amygdala (BLA) were cut at $100 \mu \mathrm{m}$ thickness and collected in ice-cold oxygenated Ringer's buffer [containing (in mM) $124 \mathrm{NaCl}, 5 \mathrm{KCl}, 1.2$ $\mathrm{NaH}_{2} \mathrm{PO}_{4}, 2.4 \mathrm{CaCl}_{2}, 1.5 \mathrm{MgSO}_{4}, 26 \mathrm{NaHCO}_{3}$, and 10 glucose, $\mathrm{pH}$ 7.4]. During all of the following procedures the slices were oxygenated continuously with $95 \% \mathrm{O}_{2} / 5 \% \mathrm{CO}_{2}$ bubbled into the incubation buffer. Three sets of experiments were performed. (1) To determine the effect of agonist stimulation on $\mathrm{SST}_{2 \mathrm{~A}}$ receptor expression and distribution, we first equilibrated slices for $40 \mathrm{~min}$ at room temperature with Ringer's buffer. Then the slices were transferred for $40 \mathrm{~min}$ at $37^{\circ} \mathrm{C}$ in the same buffer containing (experimental) or not (control) $0.01,0.1$, or $10 \mu \mathrm{M}$ [D-Trp ${ }^{8}$-SRIF, a metabolically resistant analog of SRIF. (2) To investigate the effects of neuronal activity blockade on $\mathrm{SST}_{2 \mathrm{~A}}$ receptor expression and distribution, we first equilibrated slices for $40 \mathrm{~min}$ at room temperature in Ringer's buffer devoid of $\mathrm{CaCl}_{2}$ and complemented the buffer with $20 \mathrm{~mm}$ EDTA $\left(\mathrm{Ca}^{2+}\right.$-free buffer). Then the slices were transferred to $\mathrm{Ca}^{2+}$-free buffer at $37^{\circ} \mathrm{C}$ containing (experimental) or not (control) [D-Trp ${ }^{8}$-SRIF in the same range of concentrations as above. (3) To investigate the effects of ligand internalization on $\mathrm{SST}_{2 \mathrm{~A}}$ receptor expression and distribution, we first equilibrated slices for $15 \mathrm{~min}$ in $\mathrm{Ca}^{2+}$-free or $\mathrm{Ca}^{2+}$-supplemented buffer in the presence (experimental) or the absence (control) of the endocytosis inhibitors phenylarsine oxide (PAO; $10 \mu \mathrm{M}$ ) or sucrose $0.4 \mathrm{M}$. Then we incubated them with 0.1 or $10 \mu \mathrm{M}$ [D-Trp ${ }^{8}$ ]-SRIF in the same buffers.

At the end of the incubation the slices either were fixed by incubation for $2 \mathrm{hr}$ at room temperature in $0.1 \mathrm{M}$ phosphate buffer $(\mathrm{PB}), \mathrm{pH} 7.4$, containing $4 \%$ paraformaldehyde and $0.3 \%$ glutaraldehyde for $\mathrm{SST}_{2 \mathrm{~A}}$ immunogold labeling or were processed immediately for mRNA extraction.

\section{$S S T_{2 A}$ immunogold labeling}

Light microscopy. After several washes in PB the sections were cryoprotected for 30 min in PB containing 25\% sucrose and 3\% glycerol, permeabilized by quick immersion in isopentane at $-70^{\circ} \mathrm{C}$ followed by liquid nitrogen, and thawed in PB at room temperature. After 30 min of incubation in $0.1 \mathrm{M}$ Tris-buffered saline (TBS), $\mathrm{pH} 7.4$, containing 3\% normal goat serum (NGS), the slices were incubated for $16 \mathrm{hr}$ at $4^{\circ} \mathrm{C}$ with a rabbit polyclonal $\mathrm{SST}_{2 \mathrm{~A}}$ antibody (R-88; Dournaud et al., 1996; Gu and Schonbrunn, 1997) diluted 1:1500 in TBS containing $0.5 \%$ NGS. Then they were rinsed in $0.01 \mathrm{M}$ PBS $(0.01 \mathrm{M} \mathrm{PB}, \mathrm{pH} 7.4$, containing $0.9 \% \mathrm{NaCl})$ and incubated for $2 \mathrm{hr}$ in gold-conjugated $(1 \mathrm{~nm})$ goat anti-rabbit IgG diluted $1: 50$ in PBS containing $0.2 \%$ gelatin and $0.8 \%$ BSA. Sections were postfixed for $10 \mathrm{~min}$ in $2 \%$ glutaraldehyde in PBS and washed several times in $0.2 \mathrm{~m}$ citrate buffer, $\mathrm{pH} 7.4$, after which the immunogold reaction was enhanced by incubation for $7 \mathrm{~min}$ in a silver solution (IntenSE M, Amersham, Arlington Heights, IL). The reaction was stopped by washes in citrate buffer, and the sections were mounted on glass slides for light microscopic examination.

The intensity of the light microscopic signal was quantified in the claustrum by computer-assisted microdensitometry, using a Biocom image analysis system (Les Ulis, France). Sections were examined under a Leica Orthoplan microscope equipped with a CCD camera, and nerve cell bodies labeled in the claustrum were outlined. Then labeling densities were measured over individual cells after ensuring that densitometric values were included within the linear portion of the standard gray scale (ranging from 0 to 255). Background values were determined in each section by measuring labeling densities in the corpus callosum, a region devoid of $\mathrm{SST}_{2 \mathrm{~A}}$ immunostaining, and subtracted from the corresponding totals. For each experimental condition $>20$ nerve cell bodies/region were recorded from three slices, and measurements were performed in at least three independent experiments (one rat per experiment). Data were averaged for each region and expressed as mean \pm SEM. Statistical comparison between different groups was performed with Student's $t$ test.

Electron microscopy. Sections were processed as above, but rather than being mounted on glass slides, they were post-fixed with $2 \%$ osmium tetroxide in PB for $40 \mathrm{~min}$, dehydrated in graded ethanols and propylene oxide, and flat-embedded in Epon 812 . Ultrathin sections $(80 \mathrm{~nm})$ were collected from the surface of blocks including either the claustrum or the BLA, counterstained with lead citrate and uranyl acetate, and examined with a JEOL $100 \times$ electron microscope.

Quantitative analysis of the ultrastructural distribution of $\mathrm{SST}_{2 \mathrm{~A}}$ immunoreactivity within either region was performed in ultrathin sections by counting gold particles present in the cytoplasm or associated with the plasma membrane of labeled dendrites. For each experimental condition a total of 300-400 grains was counted out of three to four grids from three independent experiments ( $n=3$ rats). Only dendrites containing at least three gold particles and exhibiting reasonably well preserved morphology (i.e., allowing for unequivocal identification of plasma membranes) were included in the analysis. The proportion of membrane-associated $\mathrm{SST}_{2 \mathrm{~A}}$ receptors was expressed as a percentage of the total number of gold particles. Statistical comparisons between groups were performed with Student's $t$ test.

\section{Quantification of $S_{S T} T_{2 A} m R N A$}

Concentrations of $\mathrm{SST}_{2 \mathrm{~A}}$ receptor mRNA were measured by reverse transcription-PCR (RT-PCR) in slices of claustrum incubated or not with [D-Trp ${ }^{8}$ ]-SRIF under the same conditions as described above for immunohistochemistry. For this purpose, first the total RNAs were extracted from pooled slices (five slices per condition for each experiment) by homogenization in $1 \mathrm{ml}$ of Trizol reagent (Life Technologies, Gaithersburg, MD) for $5 \mathrm{sec}$, followed by chloroform extraction and isopropanol precipitation according to the method of Chomczynski and Sacchi (1987). Then RNAs were suspended in $\mathrm{H}_{2} \mathrm{O}-\mathrm{DEPC}$ and frozen at $-20^{\circ} \mathrm{C}$ until use. The total amount of RNA collected from five pooled $100-\mu \mathrm{m}$-thick slices routinely ranged between 1 and $3 \mu \mathrm{g}$.

Then $2 \mu \mathrm{g}$ of total RNA per pool was reverse-transcribed with $1 \mu \mathrm{g}$ of oligo- $\mathrm{dT}_{15}$ primer (reverse transcription system kit, Promega, Madison, $\mathrm{WI}$ ) and $30 \mathrm{U}$ of AMV reverse transcriptase in a total volume of $20 \mu \mathrm{l}$ of the supplied buffer. After cDNA synthesis for $1 \mathrm{hr}$ at $42^{\circ} \mathrm{C}$ the samples were denatured for $5 \mathrm{~min}$ at $99^{\circ} \mathrm{C}$ and chilled on ice. One-tenth of the first-strand cDNA was subjected to 30 cycles of PCR in $25 \mu \mathrm{l}$ of a final reaction volume containing (in mM) $50 \mathrm{KCl}, 10$ Tris, $\mathrm{pH}$ 9, and $1.5 \mathrm{MgCl}_{2}$ plus $0.1 \%$ Triton X-100, $0.02 \%$ BSA, $200 \mu \mathrm{M}$ dNTPs, $100 \mathrm{ng}$ of sense and antisense primers, and 0.5 U Taq DNA polymerase (Appligene, Heidelberg, Germany). The first cycle was performed at $94^{\circ} \mathrm{C}$ for $2 \mathrm{~min}, 52^{\circ} \mathrm{C}$ for $2 \mathrm{~min}$, and $72^{\circ} \mathrm{C}$ for $50 \mathrm{sec}$, and the following cycles were performed at $94^{\circ} \mathrm{C}$ for $35 \mathrm{sec}, 52^{\circ} \mathrm{C}$ for $40 \mathrm{sec}, 72^{\circ} \mathrm{C}$ for $50 \mathrm{sec}$, and, for the final extension step, $72^{\circ} \mathrm{C}$ for $5 \mathrm{~min}$. PCR products were analyzed on a $2 \%$ agarose gel.

For amplification of $\mathrm{SST}_{2 \mathrm{~A}}$ mRNA, the following sets of oligonucleotides were used: (5'-CCAAGAGGAAAAAGTCAG-3') as sense primer and (5'-GATACTGGTTTGGAGGTC-3') as antisense primer, giving rise to a 373 bp band selective for rat $\mathrm{SST}_{2 \mathrm{~A}}$. Plasmid control was generated by amplifying in parallel an $X b a \mathrm{I}$ cDNA fragment encoding the mouse $\mathrm{SST}_{2 \mathrm{~A}}$ receptor subcloned into the corresponding site of the pCMV-6b expression vector. Internal standards for quantification of $\mathrm{SST}_{2 \mathrm{~A}} \mathrm{cDNA}$ were generated by amplifying glyceraldehyde-3-phosphate dehydrogenase (GAPDH) mRNA, using the following set of oligonucleotides: (5'AACCACGAGAAATATGACAAC- $\left.3^{\prime}\right)$ as sense primer and (5'CTCAGTGTAGCCCAGGA-TGCC-3') as antisense primer, giving rise to a 428 bp band. In all reverse transcription experiments two types of controls were performed: (1) each total RNA sample was subjected to RT in the absence of enzyme to control for intrinsic contamination by genomic DNA, and (2) the reaction was performed on the RT mixture without RNA added to control for contamination during the experiment.

For quantitative analysis the PCR band densities were measured by laser densitometry; ratios between $\mathrm{SST}_{2 \mathrm{~A}}$ and GAPDH cDNAs were calculated for each experimental condition. Results were expressed as a percentage of control, using as control the relative amount of cDNA present in slices superfused with Ringer's buffer (containing $\mathrm{CaCl}_{2}$ ) only. Each value was taken as the mean \pm SEM of six independent cDNA measures from two different pools of mRNA. 
Figure 1. Light microscopic distribution of $\mathrm{SST}_{2 \mathrm{~A}}$ receptor immunolabeling in claustrum slices incubated for $40 \mathrm{~min}$ at $37^{\circ} \mathrm{C}$ in Ringer's buffer $(A)$, in $\mathrm{Ca}^{2+}$-free buffer $(B)$, in $\mathrm{Ca}^{2+}$-free buffer containing $100 \mathrm{nM}\left[\mathrm{D}-\operatorname{Trp}^{8}\right.$ ]-SRIF $(C)$, and in $\mathrm{Ca}^{2+}$ free buffer containing $100 \mathrm{~nm}\left[\mathrm{D}-\operatorname{Trp}^{8}\right]$ SRIF plus $10 \mu \mathrm{M}$ PAO $(D)$. $A$, After incubation in Ringer's, intense immunolabeling is observed over nerve cell bodies and their proximal dendrites (arrows). Punctate immunostaining typical of cross-sectioned immunoreactive dendrites is also evident (arrowheads). B, After incubation in $\mathrm{Ca}^{2+}$. free buffer, the intensity of $\mathrm{SST}_{2 \mathrm{~A}}$ immunolabeling is reduced dramatically in both cell bodies and surrounding neuropil. $C$, Addition of $100 \mathrm{nM}$ [D-Trp ${ }^{8}$ ]-SRIF to the $\mathrm{Ca}^{2+}$-free incubation medium almost totally reestablishes the level of $\mathrm{SST}_{2 \mathrm{~A}}$ immunoreactivity to that seen in Ringer's controls. $D$, [D-Trp ${ }^{8}$ ]-SRIF-induced recovery of SST $_{2 \mathrm{~A}}$ immunoreactivity is totally prevented by addition of the endocytosis inhibitor PAO to the incubation medium. Scale bar, $100 \mu \mathrm{m}$.
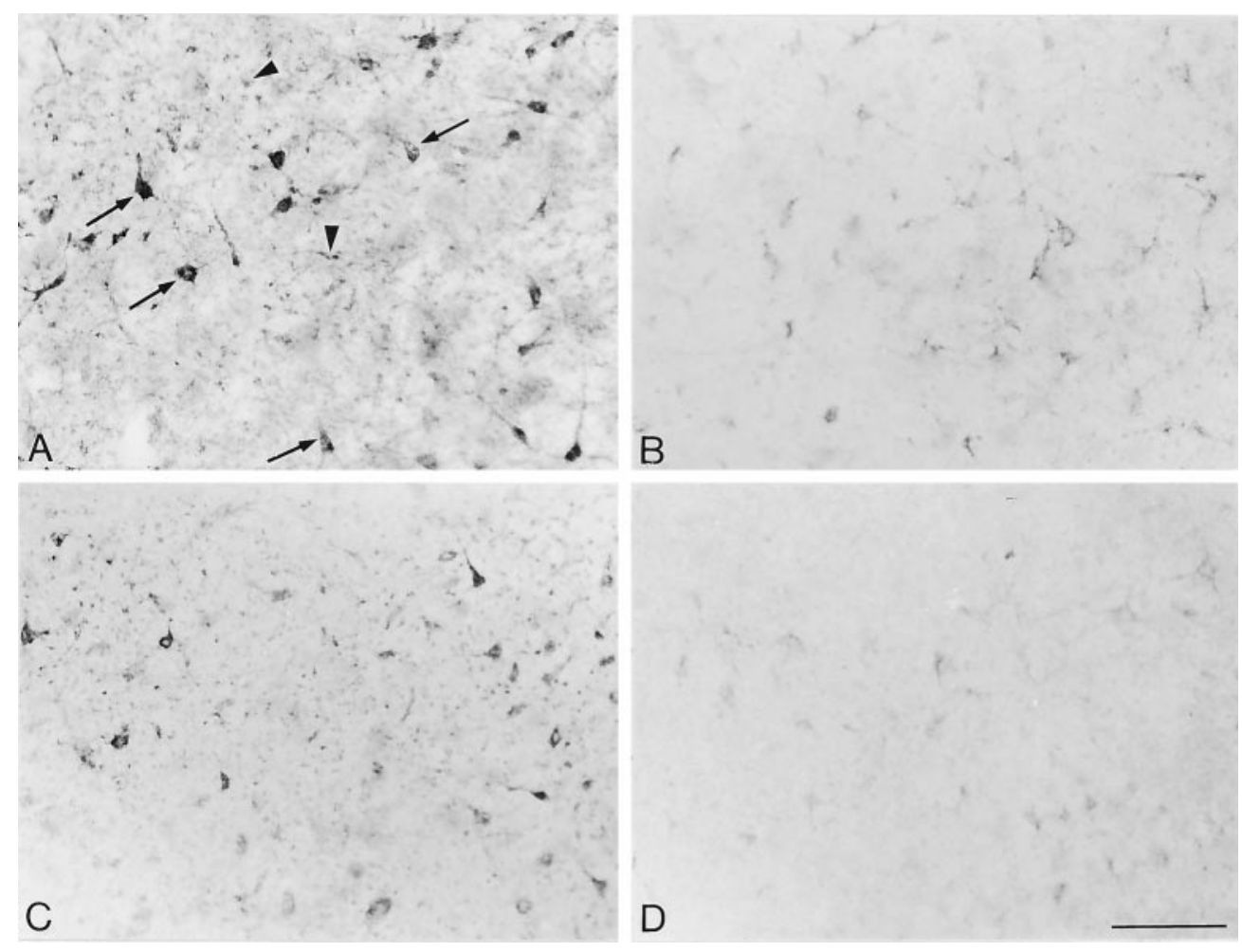

\section{RESULTS}

\section{Effect of somatostatin on the distribution and density of $\mathrm{SST}_{2 \mathrm{~A}}$ receptor immunoreactivity in the claustrum and basolateral nucleus of the amygdala}

To determine whether exposure of rat brain slices to somatostatin (SRIF) would affect the distribution and/or density of $\mathrm{SST}_{2 \mathrm{~A}}$ somatostatin receptor proteins, we examined the effect of [D-Trp ${ }^{8}$ ]SRIF on the light microscopic distribution of $\mathrm{SST}_{2 \mathrm{~A}}$ immunolabeling in two regions previously documented to exhibit high concentrations of cell surface $\mathrm{SST}_{2 \mathrm{~A}}$ receptors, the claustrum and BLA (Dournaud et al., 1996). By light microscopy the baseline $\mathrm{SST}_{2 \mathrm{~A}}$ receptor immunoreactivity was intense and mainly associated with neuronal perikarya and dendrites (Fig. $1 A$ ). Incubation of the slices for $40 \mathrm{~min}$ at $37^{\circ} \mathrm{C}$ with either 10 or $100 \mathrm{~nm}$ [D-Trp ${ }^{8}$-SRIF in Ringer's buffer containing $2.4 \mathrm{mM} \mathrm{CaCl}_{2}$ affected neither the intensity nor the pattern of $\mathrm{SST}_{2 \mathrm{~A}}$ immunolabeling in either of the two regions that were studied (data not shown). However, removal of $\mathrm{Ca}^{2+}$ from the buffer dramatically reduced both the number and staining intensity of $\mathrm{SST}_{2 \mathrm{~A}}$-immunoreactive elements in both the claustrum (Fig. $1 B$ ) and BLA (data not shown). Computer-assisted microdensitometric analysis of the intensity of $\mathrm{SST}_{2 \mathrm{~A}}$ immunostaining over neuronal perikarya labeled in the claustrum revealed a $55 \%$ reduction in the absence as compared to the presence of extracellular $\mathrm{Ca}^{2+}$ in the incubation medium (Fig. $2 \mathrm{~A}$ ).

Hypothesizing that this effect might be the consequence of the inhibition of the $\mathrm{Ca}^{2+}$-dependent release of endogenous SRIF, we examined whether stimulation with exogenous SRIF would counteract for the decrease in $\mathrm{SST}_{2 \mathrm{~A}}$ immunoreactivity observed after calcium chelation. To this aim, slices from the claustrum and BLA were exposed to increasing concentrations of [D-Trp $\left.{ }^{8}\right]$-SRIF under $\mathrm{Ca}^{2+}$-free conditions and were immunostained for $\mathrm{SST}_{2 \mathrm{~A}}$. Such a treatment resulted in a concentration-dependent increase in the intensity of $\mathrm{SST}_{2 \mathrm{~A}}$ immunoreactivity in both the claustrum (Figs. $1 C, 2 A$ ) and the BLA (data not shown). In the claustrum the intensity of $\mathrm{SST}_{2 \mathrm{~A}}$ immunoreactivity observed after the application of $100 \mathrm{nM}$ [D-Trp ${ }^{8}$-SRIF reached $80 \%$ of control values recorded in $\mathrm{Ca}^{2+}$-supplemented Ringer's (Fig. $2 A$ ).

Because it had been shown in various cell lines as well as in neurons in primary culture that stimulation with SRIF resulted in

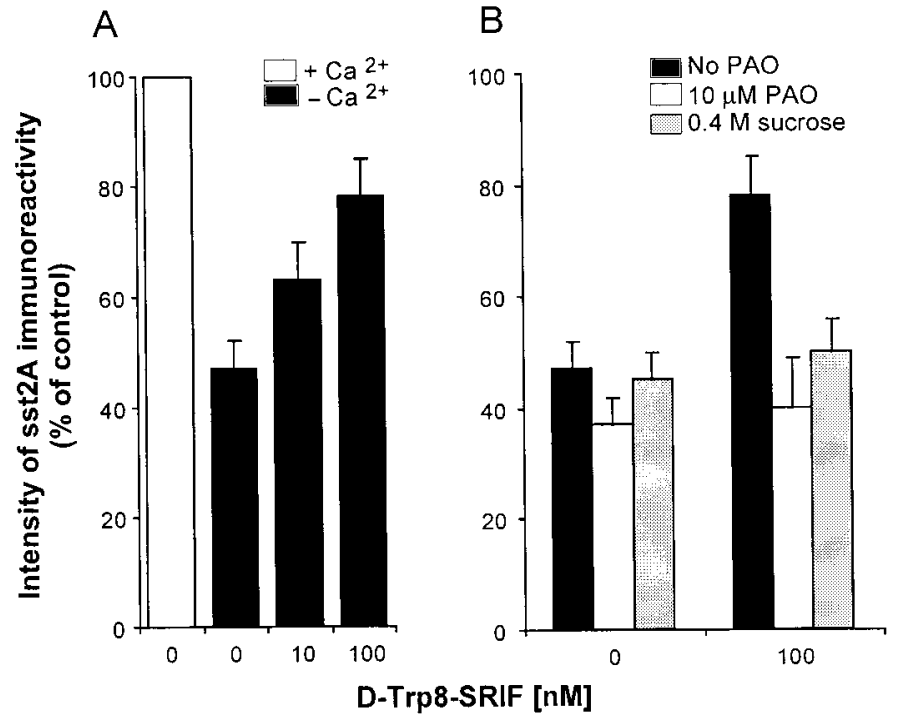

Figure 2. A, Effect of exogenous SRIF on the intensity of $\mathrm{SST}_{2 \mathrm{~A}}$ immunoreactivity in the claustrum. Slices were incubated in normal or $\mathrm{Ca}^{2+}$-free Ringer's or in $\mathrm{Ca}^{2+}$-free Ringer's containing [D-Trp ${ }^{8}$ ]-SRIF $(10-100 \mathrm{nM})$. Density of immunoreactive signal was measured over individual labeled cells with computer-assisted densitometry. Note the substantially higher level of $\mathrm{SST}_{2 \mathrm{~A}}$ immunoreactivity in the presence than in the absence of $\mathrm{Ca}^{2+}$ in the buffer and the increase in the intensity of the staining that followed agonist stimulation in $\mathrm{Ca}^{2+}$-free buffer. $B$, Effect of endocytosis blockers on the increase in $\mathrm{SST}_{2 \mathrm{~A}}$ immunoreactivity induced by [D-Trp ${ }^{8}$ ]$\mathrm{SRIF}$ in $\mathrm{Ca}^{2+}$-free medium. Slices were incubated in $\mathrm{Ca}^{2+}$-free Ringer's containing or not $100 \mathrm{nM}\left[\mathrm{D}-\operatorname{Trp}^{8}\right]-\mathrm{SRIF}$ and in the presence or the absence of $10 \mu \mathrm{M}$ PAO or $0.4 \mathrm{M}$ sucrose. Although without effect by themselves, both $\mathrm{PAO}$ and sucrose totally inhibited the SRIF-induced increase in $\mathrm{SST}_{2 \mathrm{~A}}$ immunoreactivity. Values are the mean \pm SEM from three animals.

ligand-induced receptor internalization (reviewed in the introductory remarks), we then investigated in slices from the claustrum whether the SRIF-induced increase in $\mathrm{SST}_{2 \mathrm{~A}}$ immunolabeling observed under $\mathrm{Ca}^{2+}$-free conditions was affected when endocytosis was blocked with PAO or hyperosmolar sucrose. As shown in 


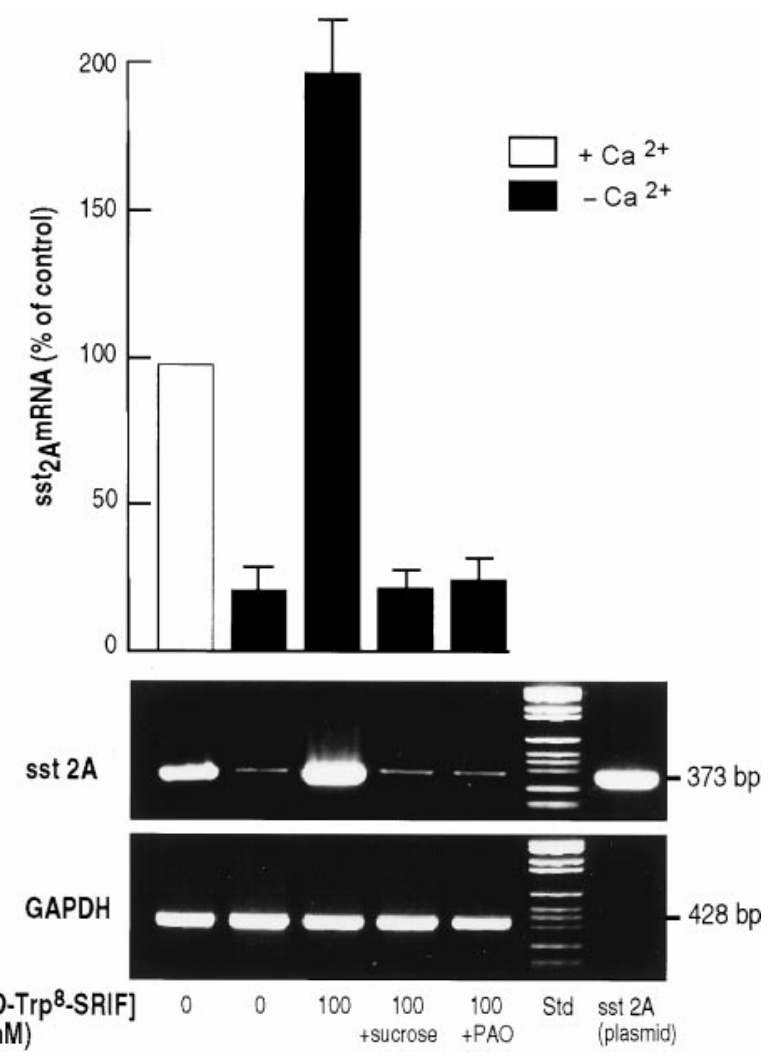

Figure 3. PCR amplification of $\mathrm{SST}_{2 \mathrm{~A}}$ mRNAs extracted from claustrum slices incubated for $40 \mathrm{~min}$ at $37^{\circ} \mathrm{C}$ in $\mathrm{C} \mathrm{a}^{2+}$-supplemented Ringer's (lane 1), in $\mathrm{Ca}^{2+}$-free Ringer's (lane 2), in $\mathrm{Ca}^{2+}$-free Ringer's containing $100 \mathrm{nM}$ [D-Trp ${ }^{8}$ ]-SRIF (lane 3), in $\mathrm{Ca}^{2+}$-free Ringer's containing $100 \mathrm{~nm}$ [D-Trp $\left.{ }^{8}\right]$-SRIF and $0.4 \mathrm{M}$ sucrose (lane 4), and in $\mathrm{Ca}^{2+}$-free Ringer's containing $100 \mathrm{nM}\left[\mathrm{D}-\operatorname{Trp}^{8}\right]-\mathrm{SRIF}$ and $10 \mu \mathrm{M}$ PAO (lane 5). PCR reactions were performed on mRNAs reverse-transcribed with specific $\mathrm{SST}_{2 \mathrm{~A}}$ receptor primers. The predicted size of amplified fragments was $373 \mathrm{bp}$ (plasmid control). GAPDH mRNAs were transcribed in parallel (target size, $428 \mathrm{bp}$ ) and used as an internal standard for quantitation. $\mathrm{SST}_{2 \mathrm{~A}} \mathrm{mRNA}$ levels, expressed as a percentage of control (Ringer's buffer), are depicted above the corresponding gel bands. All values are the mean \pm SEM of triplicate determinations from two independent experiments.

Figure $2 B$, the addition of $10 \mu \mathrm{M}$ PAO or $0.4 \mathrm{M}$ sucrose in the absence of agonist had no effect on the intensity of $\mathrm{SST}_{2 \mathrm{~A}}$ immunolabeling. By contrast, the addition of either PAO or hyperosmolar sucrose in the presence of the agonist (100 nM [D-Trp ${ }^{8}$-SRIF) totally abolished the SRIF-induced increase in $\mathrm{SST}_{2 \mathrm{~A}}$ immunoreactivity (Figs. 1D, 2B).

\section{Effect of somatostatin on $\mathrm{SST}_{2 \mathrm{~A}}$ mRNA levels in the claustrum}

To determine whether the SRIF-induced increase in the intensity of $\mathrm{SST}_{2 \mathrm{~A}}$ immunolabeling observed under $\mathrm{Ca}^{2+}$-free conditions resulted from an increase in $\mathrm{SST}_{2 \mathrm{~A}}$ expression, we determined the amount of $\mathrm{SST}_{2 \mathrm{~A}}$ mRNA present in claustrum slices before and after incubation with SRIF by semiquantitative RT-PCR, using GAPDH as the internal standard. In slices incubated for $40 \mathrm{~min}$ at $37^{\circ} \mathrm{C}$ in the absence of calcium, there was a marked decrease $(-80 \%)$ in the concentration of $\mathrm{SST}_{2 \mathrm{~A}} \mathrm{mRNA}$ as compared with controls (Fig. 3). By contrast, slices incubated in calcium-free medium but in the presence of $100 \mathrm{~nm}$ [D-Trp ${ }^{8}$ ]-SRIF showed a massive increase in $\mathrm{SST}_{2 \mathrm{~A}}$ mRNA levels as compared with levels in slices incubated in the absence of SRIF in either $\mathrm{Ca}^{2+}$-free $(\uparrow$ ninefold) or $\mathrm{Ca}^{2+}$-containing ( $\uparrow$ twofold) medium (Fig. 3). However, when the internalization process was blocked by $0.45 \mathrm{M}$ sucrose or $10 \mu \mathrm{M}$ PAO, this SRIF-induced increase in $\mathrm{SST}_{2 \mathrm{~A}}$ mRNA was no longer observed (Fig. 3).

\section{Effect of somatostatin on the ultrastructural distribution of $\mathrm{SST}_{2 \mathrm{~A}}$ receptor immunoreactivity in the claustrum and basolateral nucleus of the amygdala}

To determine whether $\mathrm{SST}_{2 \mathrm{~A}}$ receptors in the claustrum and BLA internalized on ligand exposure, we examined the subcellular distribution of $\mathrm{SST}_{2 \mathrm{~A}}$ receptor protein by electron microscopic immunocytochemistry both before and after the stimulation of brain slices with [D-Trp $\left.{ }^{8}\right]$-SRIF.

In conformity with earlier data (Dournaud et al., 1998) the bulk of $\mathrm{SST}_{2 \mathrm{~A}}$-immunoreactive receptors detected in both of these regions was associated with dendritic shafts (Fig. 4). Only rare immunogold particles were found over neuronal perikarya, axon terminals, or dendritic spines. Consequently, quantitative analyses were restricted to dendrites.

Under baseline conditions $\mathrm{SST}_{2 \mathrm{~A}}$ immunolabeling was associated mostly with the internal, cytoplasmic face of dendritic plasma membranes (Fig. 4A). The distribution of immunogold particles along these plasma membranes was rather homogeneous, and no enrichment at postsynaptic sites was observed (Fig. $4 A$ ). In both claustrum and BLA $\sim 65 \%$ of gold particles associated with dendrites overlaid the plasma membrane (Fig. 5). The remaining 35\% were intracellular and usually were associated with small-size vesicles (average diameter of $50 \mathrm{~nm}$ ). Occasionally, intracellular gold particles also were observed in association with the cytoplasmic side of larger vesicles (average diameter of $150 \mathrm{~nm}$ ) exhibiting the morphological features of endosomes (data not shown).

Incubation of brain slices for $40 \mathrm{~min}$ at $37^{\circ} \mathrm{C}$ in $\mathrm{Ca}^{2+}$ supplemented Ringer's buffer in the presence of $100 \mathrm{~nm}$ [D-Trp $\left.{ }^{8}\right]$ SRIF resulted in a slight but nonsignificant decrease in the proportion of membrane-associated gold particles within the claustrum (Fig. $5 A)$. At a higher concentration of agonist $(10 \mu \mathrm{M})$ this reduction was substantially more robust $(30 \%)$ and statistically significant $(p<0.01)$ in both the claustrum (Fig. $5 A)$ and the BLA (Fig. $5 B)$. In turn, a higher proportion of immunoreactive $\mathrm{SST}_{2 \mathrm{~A}}$ receptors was associated with endosome-like vesicles after than before stimulation with the agonist in both regions (see Fig. 4B,C). These SRIF-induced changes in $\mathrm{SST}_{2 \mathrm{~A}}$ receptor distribution were no longer observed when the incubations were performed in the presence of the endocytosis inhibitor PAO (see Figs. $4 D, 5 A$ ).

To determine whether blocking neuronal activity (including endogenous SRIF release) would affect the ultrastructural distribution of $\mathrm{SST}_{2 \mathrm{~A}}$ receptor immunoreactivity, we incubated brain slices as above in a $\mathrm{Ca}^{2+}$-free Ringer's solution containing $20 \mathrm{~mm}$ EDTA. In neither of the two brain regions that were examined did the removal of calcium from the Ringer's buffer affect the proportion of $\mathrm{SST}_{2 \mathrm{~A}}$ receptors associated with the plasma membrane (Fig. $5)$, despite its decreasing the overall density of $\mathrm{SST}_{2 \mathrm{~A}}$ immunoreactivity (see above). Furthermore, the addition of $10 \mu \mathrm{M}\left[\mathrm{D}-\operatorname{Trp}^{8}\right]$ SRIF to the incubation medium under these calcium-free conditions resulted in the same degree of cell surface receptor loss as observed in the presence of calcium in either the claustrum or the BLA (Fig. 5).

\section{DISCUSSION}

The present study demonstrates that exposure of rat brain slices to SRIF regulates the expression and availability of $\mathrm{SST}_{2 \mathrm{~A}}$ receptors in a concentration-dependent manner. This regulation is rapid $(<40 \mathrm{~min})$, involves both transcriptional and trafficking events, and is blocked by endocytosis inhibitors, suggesting that it requires internalization of receptor-ligand complexes.

The specificity of the $\mathrm{SST}_{2 \mathrm{~A}}$ antibodies used in the present experiments previously was characterized in details in heterologous transfection systems as well as in rat brain and pituitary (Dournaud et al., 1996, 1998; Gu and Schonbrunn, 1997; Mezey et al., 1998). Accordingly, the regional distribution of immunoreactive $\mathrm{SST}_{2 \mathrm{~A}}$ receptors detected here in rat brain slices was correlated closely with that of both SRIF binding sites, as visualized by autoradiography that used $\mathrm{SST}_{2}$-preferring ligands (Schoeffter et al., 1995; Holloway et al., 1996), and of $\mathrm{SST}_{2 \mathrm{~A}}$ mRNA, as detected by in situ hybridization that used either ribo- or oligonucleotide 

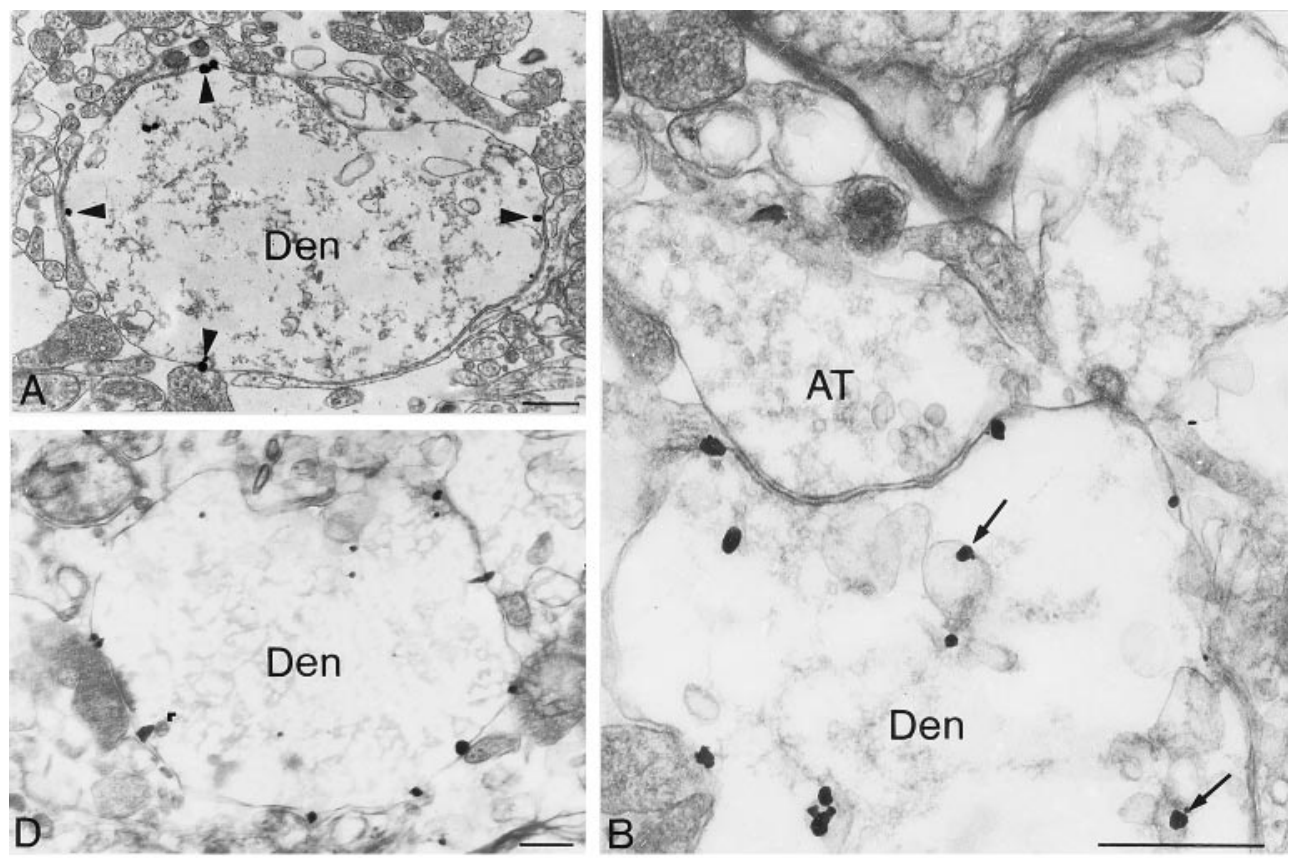

Figure 4. Electron microscopic localization of $\mathrm{SST}_{2 \mathrm{~A}}$ receptors, using silverenhanced immunogold in claustrum slices. Slices were incubated for $40 \mathrm{~min}$ at $37^{\circ} \mathrm{C}$ in $\mathrm{Ca}^{2+}$-supplemented Ringer's in the absence $(A$, control) or in the presence $(B-D)$ of $10 \mu \mathrm{M}$ [D-Trp ${ }^{8}$-SRIF. $A$, Under control conditions a high proportion of immunogold particles is associated with dendritic plasma membranes (arrowheads). $B, C$, In the presence of $10 \mu \mathrm{M}$ [D-Trp ${ }^{8}$ ]-SRIF the bulk of gold particles is intracellular. Several are seen in association with the membrane of endosomes (arrows). D, When [D-Trp ${ }^{8}$-SRIF stimulation is performed in the presence of PAO, the distribution of immunoreactive $\mathrm{SST}_{2 \mathrm{~A}}$ receptors is comparable to that seen in controls. Den, Dendrite; $A T$, axon terminal. Scale bars: $A, D, 1 \mu \mathrm{m} ; B, C, 0.5 \mu \mathrm{m}$.

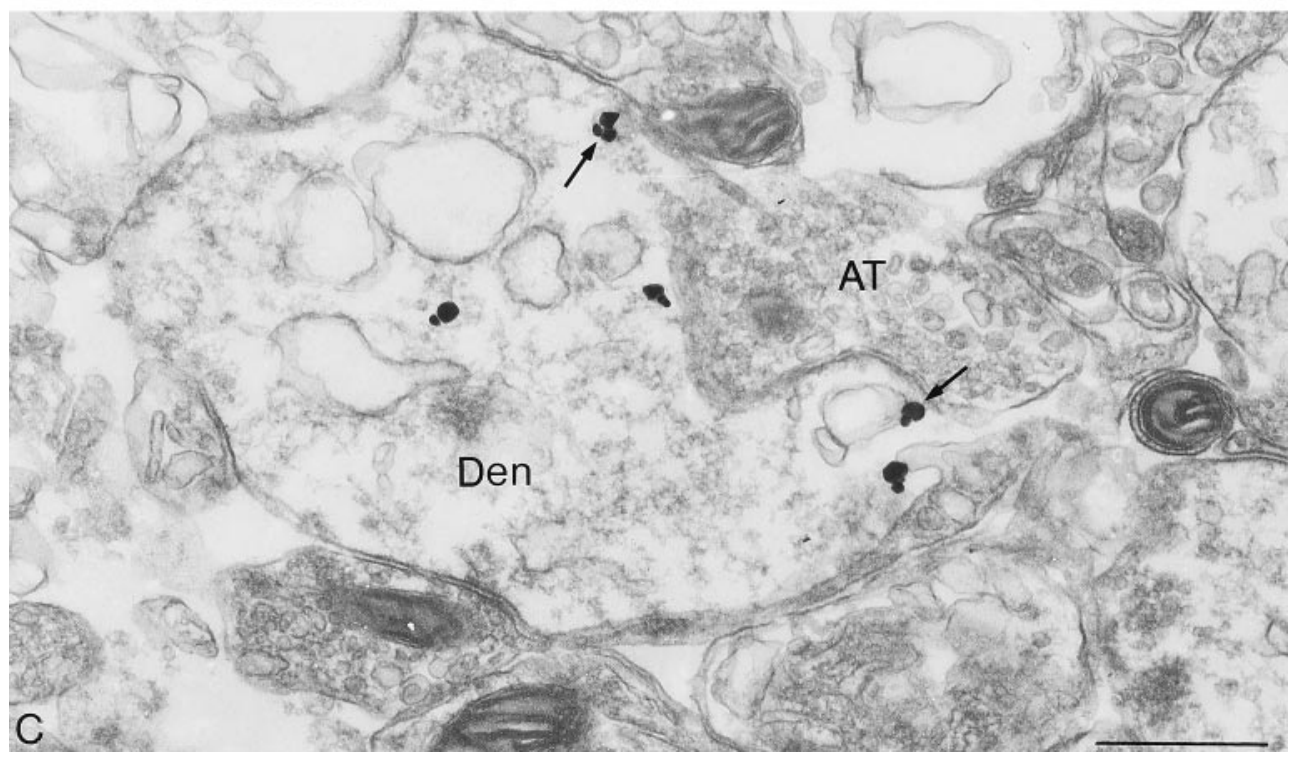

probes (Pérez et al., 1994; Señarís et al., 1994; Beaudet et al., 1995). It also conformed to that previously observed by immunohistochemistry within the same regions using either the same (Dournaud et al., 1996, 1998) or a different (Schindler et al., 1997) $\mathrm{SST}_{2 \mathrm{~A}}$ antibody.

A striking finding of the present study was that the intensity of $\mathrm{SST}_{2 \mathrm{~A}}$ immunoreactivity, expressed in terms of overall staining density, was significantly lower in both the claustrum and basolateral amygdala when the slices were incubated in the absence than in the presence of extracellular $\mathrm{Ca}^{2+}$. By light microscopy this decrease was found to be attributable to a reduction in both the number of immunolabeled neurons and neuronal processes and in the intensity of immunoreactivity within immunolabeled cells. Furthermore, measurement by quantitative PCR of $\mathrm{SST}_{2 \mathrm{~A}}$ mRNA present in incubated slices indicated that this decrease in $\mathrm{SST}_{2 \mathrm{~A}}$ receptor protein was correlated with a decrease in $\mathrm{SST}_{2 \mathrm{~A}} \mathrm{mRNA}$ levels. It is unclear whether the latter was attributable to a reduction in transcription or an increase in mRNA degradation, because both processes were shown to be involved in receptor regulation in the case of other G-protein-coupled receptors (Collins et al., 1989; Souazé et al., 1997). In any event, the present results indicate that the expression of $\mathrm{SST}_{2 \mathrm{~A}}$ receptors in neurons is under the regulation of $\mathrm{Ca}^{2+}$-dependent processes.
One of the physiological events most likely to play a role in $\mathrm{SST}_{2 \mathrm{~A}}$ regulation and clearly impaired in $\mathrm{Ca}^{2+}$-free medium is the release of endogenous SRIF from axon terminals present within the slices. We therefore investigated whether compensating the loss of endogenous SRIF release with exogenous SRIF would reestablish the levels of $\mathrm{SST}_{2 \mathrm{~A}}$ receptors to control levels, i.e., to levels observed in slices incubated in the presence of $\mathrm{Ca}^{2+}$. Incubation of slices from both claustrum and BLA with a metabolically resistant SRIF analog in the absence of $\mathrm{Ca}^{2+}$ resulted in a concentrationdependent increase in both $\mathrm{SST}_{2 \mathrm{~A}}$ mRNA, as measured by quantitative PCR, and $\mathrm{SST}_{2 \mathrm{~A}}$ immunoreactivity, as quantified by computer-assisted microdensitometry. Such an upregulation of $\mathrm{SST}_{2 \mathrm{~A}}$ receptors by SRIF was not totally unexpected because earlier studies had demonstrated an increase in SST $_{2 \mathrm{~A}}$ mRNA in GH3 pituitary cells after $2 \mathrm{hr}$ of stimulation by SRIF (Bruno et al., 1994) as well as within the arcuate nucleus of the hypothalamus 3 $\mathrm{hr}$ after systemic administration of the SRIF analog octreotide (Tannenbaum et al., 1995). More recently, long-term continuous release of octreotide for $7 \mathrm{~d}$ in tumor-bearing, severe combined immunodeficient (SCID) mice also was shown to increase $\mathrm{SST}_{2 \mathrm{~A}}$ expression in tumor cells (Froidevaux et al., 1999). In these experiments the upregulatory effects of SRIF likely were mediated by stimulation of the $\mathrm{SST}_{2}$ receptor itself, because octreotide is known 


\section{A CLAUSTRUM}

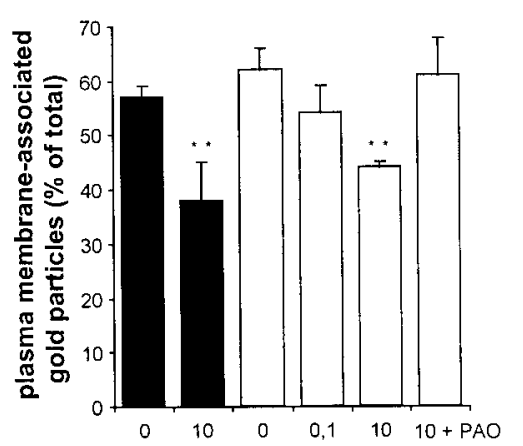

B BASOLATERAL NUCLEUS OF THE AMYGDALA

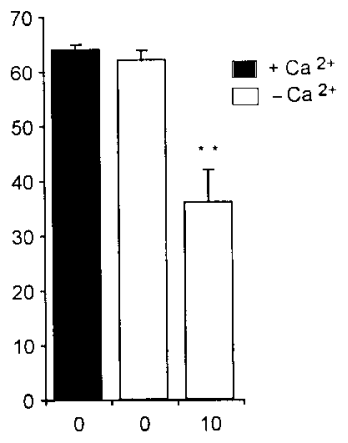

D-Trp8-SRIF $[\mu \mathrm{M}]$

Figure 5. Effect of SRIF stimulation on the subcellular distribution of $\mathrm{SST}_{2 \mathrm{~A}}$ receptors in dendrites of the claustrum and basolateral amygdala. Slices were incubated with or without [D-Trp ${ }^{8}$ ]-SRIF $(10 \mathrm{nM}-10 \mu \mathrm{M})$ in $\mathrm{Ca}^{2+}$-free or $\mathrm{Ca}^{2+}$-supplemented Ringer's. Dendrite-associated immunogold particles were counted and classified as either membrane-associated or intracellular; results are expressed as membrane-associated/total. In the absence of agonist, $\sim 60 \%$ of gold particles were associated with dendritic plasma membranes in both cerebral regions, irrespective of the $\mathrm{Ca}^{2+}$ concentration in the medium. Addition of agonist induced a decrease in the percentage of receptors associated with plasma membranes, again both in the presence and absence of $\mathrm{Ca}^{2+}$. The agonist-induced decrease in surface receptors was prevented by adding $10 \mu \mathrm{M}$ PAO to the incubation medium. Values are the mean \pm SEM from three animals; ${ }^{* *} p<0.01$.

to be relatively selective for the $\mathrm{SST}_{2}$ subtype (Raynor et al., 1993). The effects observed in our slice preparation, however, could be attributable to stimulation of any of the SRIF receptors because [D-Trp ${ }^{8}$ ]-SRIF was reported to bind to all five subtypes (Raynor et al., 1993; Patel and Srikant, 1994). It is likely, however, that $\mathrm{SST}_{2}$ was involved predominantly, given the paucity of other SST receptor subtypes demonstrated to date in either the claustrum or the BLA (Hervieu and Emson, 1998; Händel et al., 1999; Schindler et al., 1999; Stroh et al., 1999).

A striking feature of the present results is the fact that the agonist-induced increase in $\mathrm{SST}_{2 \mathrm{~A}}$ expression observed in the absence of $\mathrm{Ca}^{2+}$ was entirely prevented by the addition of PAO or hyperosmolar sucrose to the incubation medium. Both of these compounds are well documented endocytosis inhibitors acting by impeding the formation of clathrin-coated pits (Koenig and Edwardson, 1997). Admittedly, PAO also was reported to inhibit tyrosine phosphatases (Kleinert et al., 1998; Mahoubi et al., 1998) and thereby could affect cell signaling because activation of $\mathrm{SST}_{2}$ receptors was shown to inhibit cell proliferation by a mechanism involving the stimulation of the protein-tyrosine phosphatase SHP-1 (Lopez et al., 1997). However, the fact that the increase in $\mathrm{SST}_{2 \mathrm{~A}}$ receptor expression observed in the present study was abolished not only with PAO but also with hyperosmolar sucrose suggests that this transcriptional effect is really dependent on receptor internalization. Indeed, treatment with hyperosmolar sucrose has never, to our knowledge, been reported to affect intracellular signaling cascades. Furthermore, it was shown specifically not to affect forskolin-induced stimulation of adenylate cyclase (Sarret et al., 1999).

We previously demonstrated that, in the pituitary cell line AtT20, exposure to SRIF induced a decrease in growth hormone expression as measured by using quantitative PCR (Sarret et al., 1999). In this earlier study, as in the present one, the agonistinduced transcriptional effect was totally abolished in the presence of hyperosmolar sucrose, suggesting that it was dependent on internalization of receptor-ligand complexes. Similarly, chronic stimulation with a nondegradable analog of neurotensin was reported to increase NT1 receptor mRNA in HT29 cells in a PAOsensitive manner (Souazé et al., 1997). Internalization-dependent transcriptional effects therefore may prove a wider occurrence than previously was suspected.

Somatostatin has been documented to promote receptormediated internalization in a variety of cell lines (Koenig et al., 1997; Sarret et al., 1999). Studies in transfected cells have shown the efficacy of this internalization process to vary widely among $\mathrm{SRIF}$ receptor subtypes, $\mathrm{SST}_{2}, \mathrm{SST}_{3}$, and $\mathrm{SST}_{5}$ providing for the most efficient endocytosis and $\mathrm{SST}_{1}$ and $\mathrm{SST}_{4}$ providing for very poor internalization (Hukovic et al., 1996; Hipkin et al., 1997; Nouel et al., 1997; Roth et al., 1997; Kreienkamp et al., 1998; Stroh et al., 2000b). Recent studies from our laboratory have shown that SRIF internalized efficiently within neurons in primary culture and that this internalization was clathrin-dependent and mediated in part by the $\mathrm{SST}_{2}$ receptor subtype (Stroh et al., 2000a). The present electron microscopic results confirm that agonist stimulation promotes internalization of $\mathrm{SST}_{2 \mathrm{~A}}$ receptors in central neurons. This internalization is sensitive to treatment with both PAO and hyperosmolar sucrose, suggesting that it is clathrin-mediated. The net result of this internalization is a decrease in the density of cell surface receptors and a concomitant increase in the association of intracellular receptors with endosomes. This loss of cell surface receptors was observed whether or not $\mathrm{Ca}^{2+}$ was present in the extracellular milieu, in keeping with earlier studies demonstrating that clathrin-mediated endocytosis is a $\mathrm{Ca}^{2+}$-independent process (Vandenbulcke et al., 2000). Surprisingly, however, the SRIFinduced reduction in cell surface labeling was apparent only at high doses of SRIF $(10 \mu \mathrm{M})$, whereas the affinity of $\mathrm{SST}_{2 \mathrm{~A}}$ receptors for [D-Trp ${ }^{8}$ ]-SRIF is in the nanomolar range (Raynor et al., 1993). Accordingly, agonist-induced internalization of these receptors was found in other model systems to proceed within the nanomolar concentration spectrum (Hipkin et al., 1997; Koenig et al., 1997; Nouel et al., 1997). It therefore appears that relatively high concentrations of agonist are needed to downregulate cell surface receptors efficiently, presumably because at lower concentrations the recruitment of spare receptors to the membrane and/or recycling of internalized receptors compensate for the loss of cell surface ones.

The fact that a SRIF-induced decrease in cell surface receptor density was observed both in the presence and in the absence of $\mathrm{Ca}^{2+}$ and hence was irrespective of the overall concentration of receptor proteins suggests that the regulation of cell surface receptor availability and the regulation of $\mathrm{SST}_{2 \mathrm{~A}}$ receptor expression are dissociated events. Indeed, under baseline conditions (i.e., under normal extracellular $\mathrm{Ca}^{2+}$ concentrations) the transcriptional effects of SRIF have reached saturation, whereas exposure to the agonist can still decrease cell surface receptor densities. This is not to say, however, that the two events are not linked functionally. Indeed, it is tempting to speculate that the SRIF-induced upregulation of $\mathrm{SST}_{2 \mathrm{~A}}$ receptor proteins serves to compensate for the loss of cell surface receptors caused by internalization.

Taken together, the present data support the notion that dynamic transcriptional (increase in $\mathrm{SST}_{2 \mathrm{~A}}$ expression) and trafficking (loss of cell surface receptors) events are involved in the control of the somatostatinergic signal. A critical finding is that both of these events appear to be dependent on ligand-induced receptor internalization. Agonist-induced endocytosis has long been known to play a key role in G-protein-coupled receptor desensitization, including that of $\mathrm{SST}_{2}$ receptors, via cell surface receptor sequestration and downregulation (Hipkin et al., 1997; Beaumont et al., 1998). The implication of receptor endocytosis in transcriptional effects is less well established in the case of G-protein-coupled receptors, although long admitted for tyrosine kinase receptormediated signaling (for review, see Bevan et al., 1995). Recent studies have suggested that internalization may be mandatory for the activation of mitogen-activated protein kinase pathway by $\beta$-adrenergic receptors (Luttrell et al., 1999). Whether there are similar mechanisms, or others, involving either endosome signaling (Bevan et al., 1995) or translocation of internalized receptors or of fragments thereof to the nucleus (Jans, 1994; Laduron, 1994) remains to be determined. It even may be that the internalized ligand, which in transfected cells is rapidly segregated from the acidic endosomal milieu and targeted to a juxtanuclear compart- 
ment linked to the trans-Golgi network (our unpublished observations), may be acting on intracellular secondary receptors such as the $\mathrm{Ku}$ autoantigen. Indeed, this intracellular protein was documented to bind with high affinity a variety of SRIF analogs (including SRIF-28 and octreotide and therefore probably also [D-Trp $\left.{ }^{8}\right]$-SRIF) and to activate protein phosphatase 2A and DNAdependent protein kinase (Reyl-Desmars et al., 1989; Le Romancer et al., 1994; Sadji et al., 1999).

\section{REFERENCES}

Beaudet A, Greenspun D, Raelson J, Tannenbaum GS (1995) Patterns of expression of SSTR 1 and SSTR $_{2}$ somatostatin receptor subtypes in the hypothalamus of the adult rat: relationship to neuroendocrine function. Neuroscience 65:551-561.

Beaumont V, Hepworth MB, Luty JS, Kelly E, Henderson G (1998) Somatostatin receptor desensitization in NG108-15 cells. J Biol Chem 273:33174-33183.

Bevan AP, Burgess JW, Drake PG, Shaver A, Bergeron JJ, Posner BI (1995) Selective activation of the rat hepatic endosomal insulin receptor kinase. Role for the endosome in insulin signaling. J Biol Chem 270:10784-10791.

Brazeau P, Vale W, Burgus R, Ling N, Butcher M, Rivier J, Guillemin R (1973) Hypothalamic polypeptide that inhibits the secretion of immunoreactive pituitary growth hormone. Science 179:77-79.

Breder CD, Yamada Y, Yasuda K, Seino S, Safer CB, Bell GI (1992) Differential expression of somatostatin receptor subtypes in brain. J Neurosci 12:3920-3934.

Bruno JF, Xu Y, Song J, Berelowitz M (1992) Molecular cloning and functional expression of a brain-specific somatostatin receptor. Proc Natl Acad Sci USA 89:11151-11155.

Bruno JF, Xu Y, Song J, Berelowitz M (1993) Tissue distribution of somatostatin receptor subtype messenger ribonucleic acid in the rat. Endocrinology 133:2561-2567.

Bruno JF, Xu Y, Berelowitz M (1994) Somatostatin regulates somatostatin receptor subtype mRNA expression in GH3 cells. Biochem Biophys Res Commun 202:1738-1743.

Chomczynski P, Sacchi N (1987) Single step method of RNA isolation by acid guanidium thiocyanate-phenol-chloroform extraction. Anal Biochem 162:156-159.

Collins S, Bouvier M, Bolanowski MA, Caron MG, Lefkowitz RJ (1989) cAMP stimulates transcription of the $\beta 2$-adrenergic receptor gene in response to short-term agonist exposure. Proc Natl Acad Sci USA 86:4853-4857.

Dournaud P, Gu YZ, Schonbrunn A, Mazella J, Tannenbaum GS, Beaudet A (1996) Localization of the somatostatin receptor $\mathrm{SST}_{2 \mathrm{~A}}$ in rat brain using a specific anti-peptide antibody. J Neurosci 16:4468-4478.

Dournaud P, Boudin H, Schonbrunn A, Tannenbaum GS, Beaudet A (1998) Interrelationships between somatostatin $\mathrm{SST}_{2 \mathrm{~A}}$ receptors and somatostatin-containing axons in rat brain: evidence for regulation of cell surface receptors by endogenous somatostatin. J Neurosci 18:1056-1071.

Epelbaum J (1986) Somatostatin in the central nervous system: physiology and pathological modifications. Prog Neurobiol 27:63-100.

Froidevaux S, Hintermann E, Torok M, Macke HR, Beglinger C, Eberle AN (1999) Differential regulation of somatostatin receptor type 2 $\left(\mathrm{SST}_{2}\right)$ expression in AR4-2J tumor cells implanted into mice during octreotide treatment. Cancer Res 59:3652-3657.

Griendling KK, Delafontaine P, Rittenhouse SE, Gimbrone Jr MA, Alexander RW (1987) Correlation of receptor sequestration with sustained diacylglycerol accumulation in angiotensin II-stimulated cultured vascular smooth muscle cells. J Biol Chem 262:14555-14562.

Gu YZ, Schonbrunn A (1997) Coupling specificity between somatostatin receptor $\mathrm{SST}_{2 \mathrm{~A}}$ and G-proteins: isolation of the receptor-G-protein complex with a receptor antibody. Mol Endocrinol 11:527-537.

Händel M, Schulz S, Stanarius A, Schreff M, Erdtmann-Vourliotis M, Schmidt H, Wolf G, Höllt V (1999) Selective targeting of somatostatin receptor 3 to neuronal cilia. Neuroscience 89:909-926.

Helboe L, Stidsen CE, Moller M (1998) Immunohistochemical and cytochemical localization of the somatostatin receptor subtype $\mathrm{SST}_{1}$ in the somatostatinergic parvocellular neuronal system of the rat hypothalamus. J Neurosci 18:4938-4945.

Hervieu G, Emson PC (1998) The localization of somatostatin receptor 1 $\left(\mathrm{SST}_{1}\right)$ immunoreactivity in the rat brain using an $\mathrm{N}$-terminal specific antibody. Neuroscience 85:1263-1284.

Hipkin RW, Friedman J, Clark RB, Eppler CM, Schonbrunn A (1997) Agonist-induced desensitization, internalization, and phosphorylation of the SST $_{2}$ somatostatin receptor. J Biol Chem 272:13869-13876.

Holloway S, Feniuk W, Kidd EJ, Humphrey PPA (1996) A quantitative autoradiographical study on the distribution of somatostatin $\mathrm{SST}_{2}$ receptors in the rat central nervous system using [ $\left.{ }^{125} \mathrm{I}\right]-\mathrm{BIM}-23027$. Neuropharmacology 35:1109-1120.

Hoyer D, Lubbert H, Bruns C (1994) Molecular pharmacology of somatostatin receptors. Naunyn Schmiedebergs Arch Pharmacol 350:441-453.

Hoyer D, Bell GI, Berelowitz M, Epelbaum J, Feniuk W, Humphrey PPA O'Carroll AM, Patel YC, Schonbrunn A, Taylor JE (1995) Classifica- tion and nomenclature of somatostatin receptors. Trends Pharmacol Sci $16: 86-88$

Hukovic N, Panetta R, Kumar U, Patel YC (1996) Agonist-dependent regulation of cloned human somatostatin receptor types 1-5 (HSSTR 5): subtype selective internalization or upregulation. Endocrinology 137:4046-4049.

Hunyady L, Merelli F, Baukal AJ, Balla T, Catt KJ (1991) Agonistinduced endocytosis and signal generation in adrenal glomerulosa cells. A potential mechanism for receptor-operated calcium entry. J Biol Chem 266:2783-2788.

Jans DA (1994) Nuclear signaling pathways for polypeptide ligands and their membrane receptors? FASEB J 8:841-847.

Johansson O, Hökfelt T, Elde RP (1984) Immunohistochemical distribution of somatostatin-like immunoreactivity in the central nervous system of the adult rat. Neuroscience 13:265-339.

Kaupmann K, Bruns C, Hoyer D, Seuwen K, Lubbert H (1993) Distribution and second messenger coupling of four somatostatin receptor subtypes expressed in brain. FEBS Lett 331:53-59.

Kleinert H, Wallerath T, Fritz G, Ihrig-Biedert I, Rodriguez-Pascual F, Geller DA, Forstermann U (1998) Cytokine induction of NO synthase II in human DLD-1 cells: roles of the JAK-STAT, AP-1, and NF- $\kappa$ Bsignaling pathways. Br J Pharmacol 125:193-201.

Kluxen FW, Bruns C, Lubbert H (1992) Expression cloning of a rat brain somatostatin receptor cDNA. Proc Natl Acad Sci USA 89:4618-4622.

Koenig JA, Edwardson JM (1997) Endocytosis and recycling of G-proteincoupled receptors. Trends Pharmacol Sci 18:276-287.

Koenig JA, Edwardson JM, Humphrey PPA (1997) Somatostatin receptors in Neuro2A neuroblastoma cells: ligand internalization. Br J Pharmacol 120:52-59.

Kong H, DePaoli AM, Breder CD, Yasuda K, Bell GI, Reisine T (1994) Differential expression of messenger RNAs for somatostatin receptor subtypes $\mathrm{SST}_{\mathrm{R} 1}, \mathrm{SST}_{\mathrm{R} 2}$ and $\mathrm{SST}_{\mathrm{R} 3}$ in adult rat brain: analysis by RNA blotting and in situ hybridization histochemistry. Neuroscience 59:175-184.

Krantic S, Quirion R, Uhl G (1992) Somatostatin receptors. In: Handbook of chemical neuroanatomy, Chap 11, Neuropeptide receptors in the CNS (Björklund A, Hökfelt T, Kuhar MJ, eds), pp 321-346. Amsterdam: Elsevier.

Kreienkamp HJ, Roth A, Richter D (1998) Rat somatostatin receptor subtype 4 can be made sensitive to agonist-induced internalization by mutation of a single threonine (residue 331). DNA Cell Biol 17:869-878.

Krisch B, Feindt J, Mentlein R (1998) Immunoelectron microscopic analysis of the ligand-induced internalization of the somatostatin receptor subtype 2 in cultured human glioma cells. J Histochem Cytochem 46:1233-1242.

Laduron PM (1994) From receptor internalization to nuclear translocation. New targets for long-term pharmacology. Biochem Pharmacol 47:3-14.

Le Romancer M, Reyl-Desmars F, Cherifi Y, Pigeon C, Bottari S, Meyer O, Lewin MJ (1994) The 86-kDa subunit of autoantigen Ku is a somatostatin receptor regulating protein phosphatase-2A activity. J Biol Chem 269:17464-17468

Lopez F, Esteve JP, Buscail L, Delesque N, Saint-Laurent N, Theveniau M, Nahmias C, Vaysse N, Susini C (1997) The tyrosine phosphatase SHP-1 associates with the $\mathrm{SST}_{2}$ somatostatin receptor and is an essential component of $\mathrm{SST}_{2}$-mediated inhibitory growth signaling. J Biol Chem 272:24448-24454.

Luttrell LM, Ferguson SS, Daaka Y, Miller WE, Maudsley S, Della Rocca GJ, Lin F, Kawakatsu H, Owada K, Luttrell DK, Caron MG, Lefkowitz RJ (1999) $\beta$-Arrestin-dependent formation of $\beta 2$ adrenergic receptorSrc protein kinase complexes. Science 283:655-661.

Mahoubi K, Young W, Ferreri NR (1998) Tyrosine phosphatasedependent/tyrosine kinase-independent induction of nuclear factor- $\kappa \mathrm{B}$ by tumor necrosis factor- $\alpha$ : effects on prostaglandin endoperoxide synthase-2 mRNA accumulation. J Pharmacol Exp Ther 285:862-868.

Meyerhof W, Wulfsen I, Schonrock C, Fehr S, Richter D (1992) Molecular cloning of a somatostatin-28 receptor and comparison of its expression pattern with that of a somatostatin-14 receptor in rat brain. Proc Natl Acad Sci USA 89:10267-10271.

Mezey E, Hunyady B, Mitra S, Hayes E, Liu Q, Schaeffer J, Schonbrunn A (1998) Cell-specific expression of the $\mathrm{SST}_{2 \mathrm{~A}}$ and $\mathrm{SST}_{5}$ somatostatin receptors in the rat anterior pituitary. Endocrinology 139:414-419.

Nouel D, Gaudriault G, Houle M, Reisine T, Vincent JP, Mazella J, Beaudet A (1997) Differential internalization of somatostatin in COS-7 cells transfected with $\mathrm{SST}_{1}$ and $\mathrm{SST}_{2}$ receptor subtypes: a confocal microscopic study using novel fluorescent somatostatin derivatives. Endocrinology 138:296-306.

O'Carroll AM, Lolait SJ, Konig M, Mahan LC (1992) Molecular cloning and expression of a pituitary somatostatin receptor with preferential affinity for somatostatin-28. Mol Pharmacol 42:939-946.

Patel YC (1992) General aspects of the biology and function of somatostatin. In: Somatostatin (Weil C, Müller EE, Thorner MO, eds), pp 1-16. Berlin: Springer.

Patel YC, Srikant BS (1994) Subtype selectivity of peptide analogs for all five cloned human somatostatin receptors $\left(\mathrm{HSSTR}_{1-5}\right)$. Endocrinology 135:2814-2817.

Pérez J, Rigo M, Kaupmann K, Bruns C, Yasuda K, Bell GI, Lubbert H, 
Hoyer D (1994) Localization of somatostatin (SRIF) SSTR-1, SSTR-2, and SSTR-3 receptor mRNA in rat brain by in situ hybridization. Naunyn Schmiedebergs Arch Pharmacol 349:145-160.

Raulf F, Pérez J, Hoyer D, Bruns C (1994) Differential expression of five somatostatin receptor subtypes, $\mathrm{SSTR}_{1-5}$, in the CNS and peripheral tissue. Digestion 55:46-53.

Raynor K, Murphy WA, Coy DH, Raylor JE, Moreau J-P, Yasuda K, Bell GI, Reisine T (1993) Cloned somatostatin receptors: identification of subtype-selective peptides and demonstration of high-affinity binding of linear peptides. Mol Pharmacol 43:838-844.

Reisine T, Bell GI (1995) Molecular biology of somatostatin receptors. Endocr Rev 16:427-442.

Reyl-Desmars F, Le Roux S, Linard C, Benkouka F, Lewin MJ (1989) Solubilization and immunopurification of a somatostatin receptor from the human gastric tumoral cell line HGT-1. J Biol Chem 264:18789-18795.

Roth A, Kreienkamp HJ, Nehring RB, Roosterman D, Meyerhof W, Richter D (1997) Endocytosis of the rat somatostatin receptors: subtype discrimination, ligand specificity, and delineation of carboxy-terminal positive and negative sequence motifs. DNA Cell Biol 16:111-119.

Sadji Z, Le Romancer M, Hervatin F, Lewin MJ, Reyl-Desmars F (1999) Somatostatin analogs stimulate DNA-dependent protein kinase activity in human gastric tumoral cell line HGT-1. Life Sci 65:2829-2835.

Sarret P, Nouel D, Dal Farra C, Vincent JP, Beaudet A, Mazella J (1999) Receptor-mediated internalization is critical for the inhibition of the expression of growth hormone by somatostatin in the pituitary cell line AtT-20. J Biol Chem 274:19294-19300.

Schindler M, Sellers LA, Humphrey PPA, Emson PC (1997) Immunohistochemical localization of the somatostatin $\mathrm{SST}_{2 \mathrm{~A}}$ receptor in the rat brain and spinal cord. Neuroscience 76:225-240.

Schindler M, Humphrey PPA, Löhrke S, Friauf E (1999) Immunohistochemical localization of the somatostatin $\mathrm{SST}_{2 \mathrm{~B}}$ receptor splice variant in the rat central nervous system. Neuroscience 90:859-874.

Schoeffter P, Pérez J, Langenegger D, Schupbach E, Bobirnac I, Lubbert H, Bruns C, Hoyer D (1995). Characterization and distribution of somatostatin SS-1 and SRIF-1 binding sites in rat brain: identity with SSTR-2 receptors. Eur J Pharmacol 289:163-173.

Señarís RM, Humphrey PPA, Emson PC (1994) Distribution of somatostatin receptors 1,2 , and 3 mRNA in rat brain and pituitary. Eur J Neurosci 6:1883-1896.
Siehler S, Seuwen K, Hoyer D (1998) $\left[{ }^{125} \mathrm{I}\right]\left[\mathrm{Tyr}^{3}\right.$ ]octreotide labels human somatostatin $\mathrm{SST}_{2}$ and $\mathrm{SST}_{5}$ receptors. Eur J Pharmacol 348:311-320.

Souazé F, Rostène W, Forgez P (1997) Neurotensin agonist induces differential regulation of neurotensin receptor mRNA. Identification of distinct transcriptional and post-transcriptional mechanisms. J Biol Chem 272:10087-10094.

Stroh T, Kreienkamp HJ, Beaudet A (1999) Immunohistochemical distribution of the somatostatin receptor subtype 5 in the adult rat brain: predominant expression in the basal forebrain. J Comp Neurol 412:69-82.

Stroh T, Jackson AC, Dal Farra C, Schonbrunn A, Vincent JP, Beaudet A (2000a) Receptor-mediated internalization of somatostatin in rat cortical and hippocampal neurons. Synapse, in press.

Stroh T, Jackson AC, Sarret P, Dal Farra C, Vincent JP, Kreienkamp HJ, Mazella J, Beaudet A (2000b) Intracellular dynamics of $\mathrm{SST}_{5}$ receptors in transfected COS-7 cells: maintenance of cell surface receptors during ligand-induced endocytosis. Endocrinology 141:354-365.

Tannenbaum GS, Turner J, Guo F, Beaudet A (1995) Homologous upregulation of somatostatin receptor subtype SSTR $_{2}$ expression in rat arcuate nucleus in vivo. Soc Neurosci Abstr 21:1994.

Thoss VS, Pérez J, Duc D, Hoyer D (1995) Embryonic and postnatal mRNA distribution of five somatostatin receptor subtypes in the rat brain. Neuropharmacology 34:1673-1688.

Vandenbulcke F, Nouel D, Vincent JP, Mazella J, Beaudet A (2000) Ligand-induced internalization of neurotensin in transfected COS-7 cells: differential intracellular trafficking of ligand and receptor. J Cell Sci, in press.

Viollet C, Faivre-Bauman A, Zhang J, Llorens-Cortes C, Loudes C, Kordon C, Epelbaum J (1995) Differential expression of somatostatin receptors by quantitative PCR in the rat brain. C R Acad Sci III 318:851-857.

Yamada Y, Post SR, Wang K, Tager HS, Bell GI, Seino S (1992) Cloning and functional characterization of a family of human and mouse somatostatin receptors expressed in brain, gastrointestinal tract, and kidney. Proc Natl Acad Sci USA 89:251-255.

Yasuda K, Rens-Domiano S, Breder CD, Law SF, Saper CB, Reisine T, Bell GI (1992) Cloning of a novel somatostatin receptor, SSTR 3 , coupled to adenylylcyclase. J Biol Chem 267:20422-20428. 